\title{
RECIPIENT AS CANNIBAL: \\ JAPANESE CONCERNS ABOUT THE ETHICS OF ORGAN TRANSPLANTATION*
}

\author{
William R LaFleur \\ University of Pennsylvania
}

\begin{abstract}
Because organ transplantation involves the literal taking into one body of another body's parts, Japanese commentators on modern biotechnology have, at least in comparison to their Western counterparts, been willing to see parallels between such a practice and cannibalism. This survey of that difference in sensitivity suggests that it is part of the reason why Japan has been less willing to grant social acceptance to such a medical procedure. Differences between Buddhism and Christianity - since in the latter a central ritual involves the symbolic ingestion of flesh and blood - also appear to be involved in the differing ways in which organ transplantation from "brain-dead" persons has been evaluated not only by the bioethicists but also by the general populace in these two constituencies.
\end{abstract}

Keywords: Bioethics, Brain-death, Buddhism, Cannibalism, Christianity, Organ Transplantation

We have only to tap [modern medicine's] glossy veneer to split it wide open and reveal to us its roots and foundations; its old dark heart of metaphysics, mysticism, magic, and myth.

- Oliver Sachs ${ }^{1}$

Both bread and corpses,

baked with skill,

become alike

in serving as

the living ones' food.

- Naoki Fujimoto ${ }^{2}$

* Many of the ideas in this paper were presented at the Eighth International Conference on Rhetoric and the Scriptures: The Rhetoric(s) of Body Politics and Religious Discourse, sponsored by the University of South Africa in Pretoria, August 2004. I am deeply grateful to Professor Vorster, his colleagues, and the conference attendees for the opportunity to receive their comments and criticisms. A slightly different version of this paper was previously published as LaFleur, WF 2003. Der Rezipient als Kannibale: Japanische Bedenken gegenüber der Organtransplantationethik. Pages 329-341 in Menschenleben-Menschenwürde:

Interdisziplinäres Symposium zur Bioethik. Edited by MW Schweidler, HA Neumann and E Brysche.

Hamburg: LIT Verlag. Some of the materials and ideas here were presented in a lecture at the Donald Keene

Center, Columbia University, on December 5, 2000 and in a seminar at the Institute of Philosophy, Darmstadt Technological University, Darmstadt, Germany, on December 15, 2000. I am especially indebted to Professors Ryuichi Abé and Henry D Smith III for comments on the former occasion and to Professors Gernot Böhme and Rudolph Wolfgang Müller for comments on the second. Another version was presented at the interdisciplinary symposium "Menschenleben - Menschenwürde" at the Ruhr University in Bochum, November 2-3, 2001. I am especially grateful to Professor Walter Schweidler for the invitation to that symposium. Not only all translations but also all errors in this paper are entirely my own.

Sachs $(1990,48)$

2 Cf. Kobayashi $(1993,127)$. 


\section{A Tabooed Taboo}

In American bioethics there appears to be something of a taboo on mention of any conceptual or experiential parallel between some modern medical practices and what may be the closest we have to a universalized taboo among humans, namely cannibalism. The likeness between these two is, however, not unknown to patients themselves. McCann $(2000,142)$ writes of having the following experience subsequent to becoming the recipient of another person's liver: "Sometimes I woke in the middle of the night, troubled to realize that I had taken a piece of him [the donor] inside me, as if I had eaten him to stay alive."

Nevertheless, to my knowledge only three American scholars have acknowledged the analogy. Fox $(1993,238)$, in a vigorous challenge to the Pittsburgh protocols for procuring organs, referred to them as "an ignoble form of cannibalism" Kass (1994, 108; 1985, 113). wrote about some medical practices as "a sanitized form of cannibalism." And Youngner $(1996,52)$, uses the term in commenting upon the reactions of persons witnessing, even by television, the transport of re-usable organs wrapped in cellophane and carried in Tupperware coolers, as not unlike picnic food taken from one place to another. Organs, that is, seemed like transported food, parts of one person's body to be taken in - or ingested by another.

The contrast here with bioethical discussions in Japan is striking. There has been a wellinformed and sophisticated debate about cadaveric organ transplantation for several decades and within that debate the drawing of an analogy with anthropophagy has surfaced frequently. Here I will review some of these references, analyze the likely reasons for their presence in Japan, and derive from these some suggestions about where there may lie significant problems in some of the West's bioethical discussions when rhetoric about "life" begins to overwhelm what might preferably be prudential concerns about "human dignity."

At the outset, however, it seems to me worth mentioning that, at least in comparison with their American counterparts, the Japanese general public has not gotten itself inured to the assumption that cannibalism - in either noble or ignoble forms - is a phenomenon we can easily relegate to the ancient past, a characteristic of "primitive" societies and one never to be found in "advanced" societies. Cannibalism has a striking presence in modern Japanese literature and film. In response to an electronic query on this matter that I directed to colleagues in the field of modern Japanese literature, references to at least 30 titles immediately were rapidly brought to my attention. Some of these clearly show memory of the fact that, especially in the final days of World War II, Japanese military personnel remaining and starving in the jungles of southwest Asia cannibalized other humans for food. But, in addition, among the Japanese there has been wide attention given an incident in 1972 when the crash of an Uruguayan airplane in the Andes resulted in the fact that its survivors, mostly members of the rugby team of an affluent Catholic boys' school, overcame their initial aversion and, faced with starvation, ate flesh from the bodies of their fellows. When later they had survived, some of these persons confessed to having found it easier to do this if they imagined such eating to be like Holy Communion (Petrinovich 2000, 67-73). What has interested many Japanese has been the question of what processes of the mind and imagination come into play when something as strongly tabooed as anthropophagy is in one way or another given a place in even modern life. That this is related to ways in which modern medical practices may constitute "sanitized forms of cannibalism" seems clear to many Japanese. That it, in addition, is something that the promoters of such medical technologies wish to keep away from public consciousness also seems patently true. 
Although a sensitivity to this parallel had been present earlier, the publication in 1979 of a book in French on medicine and cannibalism surely encouraged a Japanese readiness to think about this analogy. Jacques Attali, who served for a time as an advisor on economics to President Mitterand, published L'Ordre Cannibale: Vie et Mort de la Médicine in 1979; it is a work that within five years had already been translated into Japanese (Attali 1984), but even to date has not been rendered into English. In an important 1988 book on the concept of "brain-death," Koyata Washida, a philosopher, gave detailed treatment to Attali's book and made a vigorous defense of recognizing what is cannibalistic in the transplantation of live organs from putative cadavers and in subsequent medical technologies that depend, falsely in Washida's view, upon the social acceptance of such transplantation as ethical (cf. Washida 1988). Moreover, in the public domain the person who served on the Japanese government's Ad Hoc Committee on Brain-death during the early 1990s and most strenuously objected to any legalization of this concept, the conservative thinker Takeshi Umehara, cited Attali's work and commented as follows:

Surely it is the transplantation of body organs that constitutes the cannibalism of our own time. One can say that in this practice there is an extension into the present of the way in which primitive peoples thought that they could enhance their own vitality by eating the flesh of other humans and the magical power derived from doing so.

If you see the look in the eyes of some transplant physicians desperate to acquire organs, you will realize that what Jacques Attali writes [about the cannibalism in such medicine] is surely not altogether wrong. Physicians who do transplants can be seen as just persons giving assistance to persons who, with the goodness of bodhisattvas, want to give their own organs to someone else. But such physicians can also be seen as assistants in cannibalistic acts. Attali's viewpoint has in it something of the cynicism of the French but, although I cannot endorse the whole of it, there is enough truth in it so that I certainly want to recommend a reading of his book by persons otherwise ready to extol organ transplantation as something worthy of praise (Umehara 1992, 234-235).

Umehara, it needs to be noted, led the movement to write what was something unusual within the world of consensus-minded commissions reporting to the Japanese government namely, the provision of a "minority opinion." Moreover, although the first legalized transplant from a person deemed "brain dead" took place, with great public attention, in 1999, the number of such transplant even today has been remarkably few.

On the matter of the parallel to cannibalism Yoshio Watanabe, a physician specializing in electro-cardiology and someone who had done advanced studies at Hanneman University in Philadelphia, sensed that in 1997 the Japanese legislature was moving in the direction of legalizing brain-death and cadaveric transplants. He publicly addressed its members in print with ten questions to which he requested answers. In the first of these he referred to the famous case of the crash in the Andes in 1972 and the passengers who ate their companions' flesh in order to survive. Watanabe went on to request that the parliamenttarians conduct a "thought experiment" in the following format:

Currently we include within the category of medicine the acts of a physician who for the purposes of transplantation cuts out the liver of a person deemed dead by the brain-death criterion. Because this practice is defined as it is, some might think it an outrageous charge for anyone to see similarities between this practice and cannibalism. But I ask: What if, hypothetically, there had been physicians among those people who survived the crash in the Andes? Would we have expected them to make their rounds cutting flesh from the bodies of the dead and feeding that same flesh to the starving - flesh, that is, which had become the only available item left to keep life going? And would we feel right in referring to such an 
action as the practice of medicine? Is there really any difference between cannibalism and cadaveric transplantation? (Watanabe 1997, 79-80).

To Watanabe himself the difference seemed either nonexistent or, at best, negligible.

\section{'Life' - Utilitarianism}

As analyzed elsewhere, a rigorous critique of the degree to which forefront medical research depends upon questionable forms of utilitarianism is a common feature of Japanese writings on bioethics and a major reason why many Japanese scholars are strongly drawn to the writings of Hans Jonas (1902-1992) the Jewish-German-American philosopher who was a critic of a simple utilitarian approach to emergent technologies (LaFleur 2002).

Koyata Washida is a philosopher of ethics at Sapporo University (the same university where Dr Juro Wada in 1968 performed Japan's first cadaveric transplant, one that many see as having been ethically compromised in multiple ways). Washida's 1988 study of brain death and transplants has a subtitle that could be rendered "Between being Human and Inhuman." It is also a book that, more than any other known to me, considers and expands upon the 1979 theses of Attali concerning the cannibalism/medicine nexus. Here I am most interested in what comes forth as Washida's argument about what he terms "seimei kôrishugi" - something that could be translated as "Life Utilitarianism." This term could alternatively be rendered as "Vitalo-Utilitarianism" because Washida is clearly uneasy about the degree to which Vitalism as a philosophy is implicitly present in much of the current international rhetoric about "saving lives," one that is used to give the greenlight to what could be unethical forms of medical research and application.

What I find especially significant in this philosopher's writing is sensitivity to how language about "life," especially when conjoined with a utilitarian-based condemnation of waste, drives forward certain research agendas that should be deeply questioned. He, for instance, writes:

The taboo against cannibalism is one we do not wish to violate. Nevertheless, we have gotten to the point where we rationalize to ourselves the re-use of various body parts of the deceased human being and we do this for the sake of [extending] the life of other humans. This life-utilitarianism, although it does not involve the eating of a corpse by ingestion through the mouth, does mean that any body-part of a corpse can be taken from it and be taken into the body of someone alive - and for the stated reason of giving happiness to the latter. And this now has gone so far that a body which looks very much alive, except for having been declared "brain dead" on the basis of one and only one criterion of measurement, can serve as one from which what, in fact, is a still beating heart will be extracted and then fitted into the body of another person. And such things are done under the aegis of an announced "good news" (gospel) declaring the importance of preserving "Life" and of extending someone's life-span. And at the same time this gets praised as proof of a victory won by medicine. The fact, however, is that a Vitalism-based Utilitarianism that is the winner in such instances. It provides a way of thinking which, while not anthropophagy via the mouth, allows for the removal and re-use of any and all parts of a body which is still alive. And it does this in order to fulfill the wish of someone else who hopes to have a longer life through this means (Washida 1988, 207-208).

What I see here, beyond Washida's claim that cadaveric transplants may be cannibalism from bodies not yet fully dead, is the suggestion that a Utilitarianism-based philosophy of 
maximized usages has been made more palatable to the general public by language about "Life" and "Life's preservation.

Washida's language here is precise. He pinpoints a strange hybrid. In our discourse about medical technologies, a secular philosophizing, the Anglo-American Utilitarianism (kôrishugi in Japanese) associated with Bentham and Mill has become yoked in a rather unholy manner to rhetoric about "Life" - that is, language that will tend to have an automatic appeal to contemporary persons as if it is an intrinsic part of the Christian gospel. The term Washida uses, fukuin, is the Japanese term denoting the specifically Christian kerugma, "gospel," or "good news."

I call attention to this easily missed point because I think it is expressive of one of the more interesting and potentially important contributions on the part of the Japanese thinkers to our more global discussions of medicine and ethics. That is, they either state or more subtly suggest that Japanese society needs to become more sensitive to two things about modern medicine: First, to the degree to which supposedly secular and universalizable positions on bioethics may, in fact, be deeply informed by specifically Western religious suppositions (the Christian gospel in Washida's account) and, second, to ways in which the rhetoric about "Life" easily invoked by ethicists in the West may be mere dressing around ethical modalities which, upon analysis, may in fact be shaped by Utilitarianism far more than by anything else. Thinkers such as Washida hint that a marriage between a crude Utilitarianism and gospel-like language about "Life" may need to be recognized as having gotten adopted in Western societies, perhaps America most especially, because of a naiveté there concerning both the conceptual and practical problems involved.

This is not unrelated to how the ideational antennae of many Japanese are differently and more sensitively attuned to pick up whatever might hint of the cannibalism nexus. Especially those Japanese writers on this topic who are consciously attempting to articulate a specifically Buddhist position in bioethics (although not Washida's own project) have been sensitive on this point. Such writers are fascinated by the likelihood that in some ways the Christian ethos and structure of symbols may be far more accommodating than is the Buddhist one to cannibalism in its various modes. Publicly expressed curiosity and concern about this is more likely to surface in Japan in the somewhat free-ranging format of the published "round-table" [zadankai] rather than in more restrained discourse of academic writing.

For instance, in such a conversation between two scholars self-identified as Buddhists published shortly after the first legal cadaveric transplantation in Japan during the Spring of 1999, an event that received extensive attention in the media there, Tetsuo Yamaori, one of Japan's best known scholars of religion and until recently the Director-General of the International Research Center for Japanese Studies in Kyoto, saw significance in the fact that, after it was clear that the rugby players in the Andes had survived their ordeal by eating human flesh, officials in the Catholic Church justified what had been cannibalism in that case. And Tetsuya Miyazaki, Yamaori's partner in conversation, saw significance in the fact that "Alive," a 1993 American film based on that tragedy, was, when shown in Japan, given a title that could be rendered as "Last Supper in the Andes" [Andesu no seisan] (Yamaori and Miyazaki 1999, 82). Although, in fact, "no one in the church's hierarchy concurred with the view that eating human flesh was equivalent to Holy Communion," (Petrinovich 2000, 72), Yamaori and Miyazaki were fascinated by the fact, as noted above, that some of the survivors in the Andes related that their own eating of human flesh was made easier if they imagined it to be like that of Holy Communion. Miyazaki went on to state: "The ideational background to the practice of cadaveric organ 
transplantation is very closely bound up with modernity but at the same time it is linked to Christianity to an extraordinary degree - as is the notion of one person laying down his life for others" (Yamaori and Miyazaki 1999, 83). ${ }^{3}$

There probably can be no unanimity about whether organ transplantation is a justifiably medicalized extension of the central Christian rite or, alternatively, something concerning which many Christians in the West have been seduced into supporting simply by the subtle manner in which practices shaped, in fact, by a secularized Utilitarian philosophy have been made ethically presentable via concepts and terms of the West's major religion (see LaFleur 2001). To many Japanese these are matters of curiosity. And they are also ones of concern if newly emergent medical technologies may have implicit, within themselves unrecognized, but powerful modes of Western thought and religion. Portrayed as strictly secular, they may, in fact, at bottom be at variance with, even disruptive of, the traditional religious and philosophical traditions that many Japanese wish to retain, not lose through inattention.

One consequence of this sensitivity has been an effort in Japan to define a more distinctively Buddhist view of the life/death question - with the hope that such may, in turn, be reflected in a bioethics that is not simply a mirror image of that enterprise in the West. For instance, the fact that in Buddhist thinking death is intrinsic to the nature of things and not present in our world by the contingent fluke of human sinfulness has led some Buddhists to note that, if death is what they claim it to be, they at least ought not use language about something uniformly positive termed "Life" being opposed on both a practical and rhetorical level by something always and necessarily negative termed "death." In, for instance, a volume of collected essays on death in the history of Buddhist thought, Aiyoshi Kawahata, formerly a professor at Kyoto University and the head of an institute on medicine, has written:

[For Buddhists] death is a universal natural phenomenon and at the same time the necessary consequence of biological functioning. Dying and being born go together in the same way as darkness and light. Death has its basis in cosmic law and is a constitutive part of the workings of such law. In Buddhist terms this is expressed as the fact that all things undergo change within the Dharma. Or within the coordinates of vast space and the infinite reach of time coming into being (birth) and passing away (death) are linked phases and ultimately not separable. Thus death ought not to be thought of as a unique, foreign, or unusual phenomenon (Kawahata 1988, 445).

Of importance to Japan's Buddhists is the articulation of their own traditional view of death. While in no way allowed to lessen the resolve to avoid killing, this view avoids conceptualizing a cosmic, almost Manichean, battle between a force of Life prized as absolutely positive and its opposite, a totally negative force called "death."

\section{Imagining the Future}

In the extensive Japanese writing about the future of medical and reproductive technologies it would be very difficult to find anything like the level of utopian sanguinity to be found, for instance, in writings by Americans such as Lee M. Silver (1997), a Princeton biologist, or Stanford University's Carl Djerassi (2001), a chemist. Perhaps a greater awareness in Japan, comparable to that in Germany, concerning horrible mistakes of the past in the

An explicit linkage between the crucifixion and the donation of organs by a dying person is made in the 1990 Canadian film "Jesus of Montreal." 
domain of medical research acts as a brake and reason for caution. Explaining why it is that, even after it had become legal in Japan, she will not sanction the transplantation of organs from bodies deemed "brain dead," Tomoko Abe, a pediatrician who had done advanced work at the Mayo Clinic, writes:

Knowledge of what Germans did during the Nazi period in terms of turning flesh taken from Jewish bodies into items of everyday utility (with lampshades of skin the well-known example) and knowledge too of what our own Japanese military did in China in terms of referring to their Chinese prisoners as "logs" and then subjecting them to vivisections constitute knowledge that results, for us, in a loathing, fear, and introspective thinking about history whenever we are confronted with certain kinds of medical experimentation. As a result we feel as if paralyzed when face-to-face with the details of cadaveric organ transplantation and the widespread reuse of human body parts (Abe 2000, 43).

My own view is that this historical memory, however painful, operates somewhere within the consciousness of many Japanese so that, compared to their English and American counterparts, there is within the general public in Japan more wariness and suspicion about medical research agendas that are promoted in glowing, utopian terms. Easy talk about extending life, ending illness, and giving us the chance, through biotechnology, to design with total rationality the babies of the future does not wash so easily in Japan. And it is this greater wariness $v i s-a ́$-vis touted technologies and their utopian products that takes shape in a greater readiness to see subtle links between such medical practices and the horrors of cannibalism. It suggests how present practices might, when dressed up in language of "Life" and its limitless extension, be setting in process events that could become horrors from which we will someday recoil. Yamaori writes that one of the many problems with cadaveric transplantation is how it might just be servicing as a "dress rehearsal" for even more blatantly utilitarian procedures in the future (Yamaori and Miyazaki 1999, 77).

This has meant a much greater vigilance in Japan vis-à-vis new technologies and procedures, especially if advocated in terms of their usefulness. By contrast, other practices which, although morally problematic, are ancient and will not be argued for in the language of Utilitarianism are of less concern. Concretely this means that abortion, a practice that appears to have been a part of human experience for as long as we know, is not seen as harboring the same level of danger and warranting the same level of prudential wariness. Far more worrisome are technologies, precisely because they involve much more likelihood of having unanticipated consequences and these are consequences which could begin to change the nature of human nature as we have always known it. When scientists such as Silver write of being willing to countenance the simultaneous co-existence of two human species, one of which is new and constituted of individuals who have been genetically "improved," we sense that we are facing ethical dilemmas whose ramifications outstrip by far the ancient ones such as that of abortion.

Here is where the Americans and Japanese are most likely to diverge. Within the United States there are persons who, while otherwise opposed to legalized abortion, will, when presented with data indicating that pluripotent embryonic cells might be eminently useful for research and therapy, tend to be swayed by this argument about utility, especially if in the service of Life and its extension. Many Japanese, by contrast, become not less, but more worried precisely when the argument about utility enters the picture. Some of the most reprehensible acts of the past were couched in arguments about their patent usefulness either in the short or longer run. The vivisections conducted by Unit 731 in occupied China were eminently "useful" in the advancing knowledge about the human body. 
The body parts of the "brain-dead" person are like embryonic cell formations in that their use becomes conspicuously valuable, even commodifiable. One person will live on or live better because the body of some other has been taken in, used, and consumed. We then become, through technologies that so distance entities from one another that we cannot see their connections, consumers of one another. This is the trajectory onto which the so-called cadaveric transplant some decades ago placed us. Our much touted, "miraculous," technologies may have turned us into a society that lets itself practice what, in the words of Tsuyoshi Awaya, a Professor of Law at Tokuyama University and the author of a major critique of Utilitarianism in bioethics, can only be called "neo-cannibalism" [neokanibarizumu] (Awaya 1998, 88).

At the conclusion of an essay in one of the most important volumes of Japanese thinking about bioethics - and one inclusive of a significant essay by Kei'ichi Tsuneyoshi on Japanese war atrocities in the name of eminently useful medical research - Awaya wrote the following:

In our time medical technology continues to act like the tractor pulling contemporary civilization. It can be said that what we call "civilization" is the system for satisfying human desires. But even more accurately it is the system that not only satisfies but also produces ever new and greater desires. Things then come to be ruled by how useful they may be or how they fit into utilitarian ways of thinking. It is crucially important to see and understand organ transplants within this context. They satisfy the desire of a person to extend his or her life ... for even a single year or a mere month.

I, however, am insisting that we refer to such change with respect to the human body and even to humanity itself as "medical technology's revolutionary change in the nature of the human being." And the phenomenon of organ transplantation was in the forefront of this historic change. Organ transplantation, therefore, is not just something involving a donor, a patient and the physician. And, thus, decisions concerning it may not be confined simply to what is to be done to help the concrete patient on the immediate scene. What has to be decided is really a matter having to do with our whole civilization. And is it not the case that things have come to the point where questions about the direction being taken by civilization itself must be asked? (Awaya 1998, 96-97).

In his important and widely read book on brain-death, Masahiro Morioka (1991), having surveyed some of the references to this nexus in Japanese writings, noted:

Cannibalism consists of human beings eating the flesh of their fellow humans and is the greatest taboo to be found within the human race. Yet surely, acts in which the body organs of a fellow human, even if not ingested through the mouth, are taken into one's own body can easily be seen as at least one form of cannibalism. It can, thus, be expected that a large number of people will find in themselves a certain mixing of the images of cannibalism with those of organ transplantation ... I suspect that this is the reason why, when people contemplate cadaveric organ transplantation there often arises within them what at first sight would seem a wholly irrational revulsion and antipathy. Is this not because from deep within ourselves there arises a dark shadow associated with cannibalism? (Morioka 1991, 86-87).

It would be a mistake to assume that Morioka is charting sentiments to be found only within his fellow Japanese. Leon Kass (1998) has referred to what he calls "the wisdom of repugnance" and in conversation Arthur L Caplan has detected what he calls the "yuk factor" in procedures such as the cadaveric transplant. So the difference between Japan and America here may be less than we would ordinarily assume. Statements such as the one from McCann $(2000,142)$ cited early in this essay suggest that also in the minds of many 
Americans, although usually suppressed, there is a sense that there is something vaguely cannibalistic in the cadaveric transplant. Perhaps this is part of the reason why resistance to becoming organ donors remains surprisingly high in America, in spite of intensive and ongoing campaigns advocating that people become donors and in the face of what has been the creation of a moral ambience that makes it embarrassing to be a non-donor there. The fact that increasingly high incentives, now even contemplated monetary ones, have become necessary to increase the number of donors and through this to procure organs can be seen as the evidence of residual resistance. What Morioka in the quote just above calls the "dark shadow associated with cannibalism" may not be as far away as American writing about bioethics tends, by its nearly constant silence on this question, to suggest.

\section{BIBLIOGRAPHY}

Abe, T 2000. Bunka toshite shi no kaitai to ningen no kaitai o maneku (Nôshi, zôki ishoku). Pages 26-56 in Watakushi wa zôki o teikyô shinai. Edited by K Makoto, M Nakano, T Miyazaki and. Yoshimoto. Tokyo: Yôsensha.

Attali, J 1984. Kanibarizumu no chitsujo: Sei to wa nanika, Shi to wa nanika. Translated by S Kanezuka. Tokyo: Misuzu shobô.

---- 1979. L'Ordre Cannibale: Vie et Mort de la Médicine. Paris: Éditions Grasset \& Fasquelle.

Awaya, T 1998. Zôki ishoku to hito kakumei. Pages 71-97 in Seimei rinrigaku kôgi: Igaku iryô ni nani ga towarete iru ka. Edited by A. Kôyama. Tokyo: Nihon hyôronsha.

Djerassi, C 2001. This Man's Pill: Reflections on the $50^{\text {th }}$ Birthday of the Contraceptive Pill. Oxford: Oxford University Press.

Fox, RC 1993. “An Ignoble Form of Cannibalism”: Reflections on the Pittsburgh Protocol for Procuring Organs from Non-Heart-Beating Cadavers. Kennedy Institute of Ethics Journal 3(2): 231-239.

Kass, LR 1998. The Wisdom of Repugnance. Pages 3-59 in The Ethics of Human Cloning. Edited by LR Kass and JQ Wilson. Washington: The AEI Press.

1994. The Hungry Soul: Eating and the Perfecting of our Nature. Chicago: University of Chicago Press.

---- 1985. Toward a More Natural Science: Biology and Human Affairs. New York: Free Press.

Kawahata, A 1988. Shi o megutte no igaku to bukkyô: Anrakushi, songenshi, shi o meguru igakuteki hantei. Pages 403-458 in Shi. Edited by H Nakamura, S Kumoi, K Tamaki, Y Tamura and K Fujita. Kyoto: Heirakuji shoten.

Kobayashi, M 1993. Yamairon no genzairon. Tokyo: Seikyûsha.

LaFleur, WR 2002. Philosophy and Fear: Hans Jonas and the Japanese Debate About the Ethics of Organ Transplantation. Pages 249-267 in Komparative Ethik: Das "gute Leben” zwischen ostlichen und westlichen Denkwegen. Edited by R Elberfeld and G Wohlfart. Köln: Edition Chora.

---- 2001. From Agapé to Organs: Religious Difference between Japan and America in Judging the Ethics of the Transplant. Pages 272-290 in Ethics in the World Religions. Edited by J Runzo and NM Martin. Oxford: One World. 
McCann, R 2000. The Resurrectionist. Pages 135-147 in Body: Writers Reflect on Parts of the Body. Edited by S S Fiffer and S. Fiffer. New York: Perennial.

Morioka, M 1991. Nôshi no hito: Seimeigaku no shiten kara. Tokyo: Fukutake bunko.

Petrinovich, L 2000. The Cannibal Within. New York: Aldine De Gruyter.

Sachs, O 1990. Awakenings. New York: Harper Collins.

Silver, LM 1997. Remaking Eden: How Genetic Engineering and Cloning Will Transform the American Family. New York: Avon Books.

suzuki, S 1996. "Seimei" de yomu Nihon kindai: Taishô seimeishugi no tanjô to tenkai. Tokyo: NHK Books.

Umehara, T 1992. Nôshi - Sokuratesu no to wa hantai suru: seimei e no kyôfu o wasureta gôman na "nôshi" o haisu. Pages 207-236 in "Nôshi" to zôki ishoku. Edited by T Umehara. Tokyo: Asahi shimbunsha.

Washida, K 1988. Nôshiron: Ningen to hiningen no aida. Tokyo: San'ichi shobô.

Watanabe, Y 1997. Kokkai giin e no ju no shitsumon. Pages 79-89 in Ai desu ka? Zôki ishoku. Edited by T Abe and F Matsumoto. Tokyo: Shakai hyôronsha.

Yamaori, T and Miyazaki, T 1999. Nôshi rongi no ôkina ketsuraku. Ronza (May): 74-87.

Youngner, SJ 1996. Some Must Die. Pages 32-55 in Organ Transplantations: Meanings and Realities. Edited by J Stuart, R Youngner, C Fox and LJ O'Connell. Madison: University of Wisconsin Press. 